\title{
Research on Ecologization of Sports Class Teaching in Colleges
}

\author{
Yumei Lu \\ Minnan Science and Technology Institute of Fujian Normal University \\ Quanzhou, China 362332
}

\begin{abstract}
Problems in sports class teaching in colleges are researched from the perspective of ecology, including: imbalance of ecosystem in sports class teaching, absence of students' dominant position and backwardness of sports culture on campus. Countermeasures are as follows: Establish the concept of ecological teaching; actively cultivate subjects of sports class teaching; roundly create good ecological environment for sports class teaching.
\end{abstract}

Keywords—colleges; sports class teaching; ecology

\section{INTRODUCTION}

Under the influence and promotion of "lifelong sport", we should think about problems related to ecologization of sports class teaching. According to current situation of ecologization of sports class teaching, teaching ecological system will be built and scientific mechanism for ecological operation of college sports class is explored.

\section{ECOLOGIZATION OF SPORTS TEACHING}

"Ecologization" means analyzing relationship and operation rules of factors in the system from system theory and finding the dynamic change and coordinated development between it and the environment. Early in 1932, the word "ecology" was formally applied to educational field. The concept of "ecologization of higher education" was proposed in 1966. Foothold and ultimate goal of sports are close to the center of "ecology". For years, scholars at home and abroad have explored composite factors in higher education and the relationship and balance between factors. Sports class teaching is a micro dynamic system to realize balance and development among teachers, students, teaching environment and contents.

\section{IMPORTANCE AND NECESSITY OF ECOLOGIZATION OF SPORTS TEACHING}

Sports effectively promote students' integrated development. Under the development demand of modern sports, ecologization of sports teaching corresponds to ecological civilization of sports. In the era calling for

Class A project of education and research development in Fujian province "Research on Promoting College Students' Consciousness in Physical Exercise under the Perspective of Lifelong Sport-Take Colleges in Fujian as Examples" (No. JAS14814), the second result of research project (No. JG2014005) in teaching reform of Minnan Science and Technology Institute of Normal University. systematicness, integration, balance and harmony, sports teaching also need balance and sustainable development. Soaring development of science and technology has made sports class teaching increasingly technological. It is distinctly important to explore ecologization of sports teaching with extensive technology application. Reviewing sports teaching from the perspective of ecology can promote harmonious development of sports teaching.

\section{A. Intrinsic Requirements for Harmony of Teachers and Students, Teaching Environment and Teaching Contents}

According to two development periods of ecology, shallow ecology is to improve ecological environment and seek long-term survival and development; deep ecology is not just limited to natural ecology but values vital interests of subjects. Higher education has transformed from elite education to mass education. Sports teaching also experience the transformation from simply changing teaching environment to paying more attentions to subjects in class teaching. In order to realize dynamic balance among the three, sports class teaching must be ecological. Except for teaching environment, more attentions must be paid to spiritual ecology of sports teaching. Therefore, in order to meet college students' requirements for increasingly affluent class teaching, ecologization of sports teaching is also an important subject that urgently needs to be solved. To establish ecological sports development system, we must use the value idea of regeneration to actuate the development of sound system in college sports. Ecologization means pursuing ecological existence of sports with higher quality.

\section{B. Inevitable Requirement of "Lifelong Sport" Idea}

Since the concept of "lifelong sport" was proposed in sports circle in the 1990s, as basic and critical period of lifelong sport, college sports have shouldered vital responsibility. In ecological construction of sports teaching, colleges must strengthen the consciousness lifelong exercise and integrate "lifelong sport" in management and education to form long-term exploration mechanism. School education is long term instead of short term. According to college students' law and characteristics of physical and mental development, school education must guide college students to establish correct sports view through scientific and effective methods, keep sports consciousness and understand sports law and grasp exercise method, experience the charm of sports and the happiness brought by it. 


\section{CuRrent Situation OF ECOlOGIZATION OF SPORTS Class TEaChING IN COLLEGES}

\section{A. Imbalance of Ecological System of Sports Class Teaching}

Ecology of sports class teaching means observing college sports teaching through ecology. According to educational background, at elementary education stage, inadequate attention paid to sports makes college students hold relaxed and indifferent attitudes toward sports class teaching in colleges. On one hand, they think sport is unimportant; on the other hand, they are not enthusiastic in sports activities. It explains why contemporary college students' physique is below expectation. According to covariation in ecological theory, adaptation and interaction among elements in the system will influence the entire system. As an important part of education ecology in colleges, sport class teaching is inseparable from teachers' teaching emotion and students' performance in class and willingness in activities. To a great extent, it is because the thought of "lifelong sport" fails to enjoy popular support. The thought of "lifelong sport" arouses students' enthusiasm in participating in sports activities meanwhile effectively promotes sustainable development of college sports. At present, ecological system of college sports class is imbalanced. Ecological classroom hasn't been established yet.

\section{B. Absence of Students' Dominant Position}

In higher education stage, most gym teachers still follow the traditional teaching patterns and methods. In class, teachers dominate and spend most of the class hour in technique teaching, making college students less creative. Generally speaking, students learning the same sport event are in the same class, such as shadowboxing class and aerobics class. Teachers instruct students under technical standard and assess them. The most fundamental goal of college sports class is to teach students basic knowledge about fitness through sport events, to strengthen their fitness consciousness and develop the habit of taking exercise. However, sports class teaching quantifies it through technical examination. Students haven't dominant position and it cannot meet their individualized learning needs.

\section{Backwardness of Sports Culture on Campus}

Sports have unique cultural value. As important ecological environment of college sports, the influence of sports culture on campus on sports class teaching cannot be ignored. Colleges have varied literary and artistic activities, but the construction of sports culture still remains in shouting slogans and holding sports meetings. It separates from cultural construction in colleges. As "factor" of ecologization of sports class, it directly influences sports construction. "Ideology guides actions". Colleges haven't fully recognized the significance of sports culture construction ideologically. The functions of sports culture are not embodied. Under the environment of cultivating and carrying forward the socialist core values, colleges neither value sports culture construction and nor regard it as important carrier and platform for education.

\section{WAYS TO REALIZE ECOLOGIZATION OF SPORTS Class TEACHING IN COLLEGES}

To realize internal coordinated development and longterm development of sports cause, as a microcosmic ecosystem, sports class teaching in colleges must make the following breakthroughs:

\section{A. Establish the Idea of Ecologization of Sports Class Teaching}

Political, economic and cultural environment in any era will influence education, requiring the adjustment of educational ideas and methods. Nowadays, the historical background requires the establishment of ecological concept in sports class teaching in colleges. Adhering to the principle of "health first", according to the requirement that higher education must teach basic sport skills, schools have to build scientific and reasonable ecological teaching objectives and contents, in order to improve college students' sports quality and promote sustainable development. In other words, ecologization of sports class teaching means using ecology to create harmonious ecological environment of sports class teaching. More attentions are paid to interaction between teachers and students, to make class teaching more dynamic.

\section{B. Actively Cultivate Ecological Subject of Sports Teaching}

To create good atmosphere of sports class, equal, harmonious and democratic relations between students and teachers must be built. It intrinsically requires us to actively cultivate ecological subject of sports teaching. Ecological subject is the product of ecological environment and acts on the ecological system, promoting continuous change of ecological system. In ecological system of college sports, undoubtedly, teachers and students are dominant factors. Students are limited to teaching ecology and directly influence the ecological environment of sports class. We must actively cultivate subjects of teaching ecology. Teachers have to ceaselessly improve professional quality and level, and take initiative to explore teaching methods, at the same time use advanced teaching idea to strengthen college students' ideology and consciousness of "lifelong sport". The important precondition is that college students have positive sports view and outlook on life. Besides, teachers in sports class should fully "teach students in accordance with their aptitude". Examination is not the goal but means. Therefore, teachers have to formulate dynamic assessment criterion and adjust teaching objectives according to different teaching objects, so that students can develop good consciousness and habit of physical exercise.

As ecological subject, students should develop good psychology of sports ecology. Students' mental state has important influence on teaching effects. If students have positive and open psychology of sports ecology, they will take initiative to learn and have enthusiasm in participating in sport activity and interact and share with teachers. Teachers have to grasp students' positive ecological psychology in teaching and make teaching contents and environment coordinate with teaching reaction of subjects. Teachers can stimulate students' positive ecological 
psychology through martial arts and music, waltz and make the classroom more appealing.

\section{Roundly Create Good Ecological Environment of Sports Class}

In ecological system, the better the environment, the more appealing it will be. Except for teaching and learning, sports class teaching should create high quality environment in relations between students and teachers and the selection of teaching materials.

1) Build ecological sports course system:Course system is the core for ecologization of sports class teaching. Sport courses must be interesting and open with general education, combine personality and diversity and have high participation willingness of individuals. Curriculum provision must fully consider students' diversity, hobbies and interests and difference in learning ability and creativity. Meanwhile, courses must be innovative and interesting. Contemporary college students have appeal of their own. Course system should be more reasonable and ecological according to college students' characteristics, in order to realize effective development among teachers and students and teaching contents as well as environment.

2) Strengthen the construction of sports culture on campus: German biologist Ernst Haeckel defines ecology as the science related to the relation between living body and its surroundings. Sport teaching has important relations with ecological environment. What is ecological environment? It includes hard environment and soft environment. Sports culture on campus is important embodiment of environment. The construction of sports culture on campus is not isolated in colleges. From the systematic and integral perspective, the construction of college sports culture intrinsically supports ecological system of sports class teaching. It is distinctly important. Culture has important educational function. Colleges should value the construction of sports culture and popularize concepts and knowledge of sports with the help of traditional media and new media. Meanwhile, characteristic sport activities must be organized such as art festival of sports activities and fun sports meeting to attract teachers and students. Culture includes material culture and spiritual culture. Material sports culture embodies in sports facilities and sports field. Dewey observes, "School is a special environment and uses special equipment to educate". School environment plays an important role in ecological system of college sports. With the popularization of higher education, the bearing capacity of sports environment in colleges also faces serious challenges. Sports hardware facilities such as tennis court and basketball court cannot reach the standard per capita. It will seriously influence sports class teaching, so will environmental imbalance. In this way, cultural construction is only "castle in the air". As important carrier of culture, colleges must guarantee students have good hardware of sports culture. Cultural construction is not easy, so composite force must be formed to cultivate students' consciousness of keeping pace with the times.

3) Ecological development of gym teachers: Teaching level and comprehensive quality of gym teachers are important in ecological system of sports teaching. Gym teachers should take advantage of high quality environment, continuously strengthen theoretical learning and improve ability to understand teaching materials. Teaching objectives and contents must be established according to college students' physiological and psychological characteristics. Gym teachers' growth and development cannot separate from long-term teaching practice. In teaching process, as organizer, implementer and guide of the class, teachers must conclude teaching law and grasp teaching characteristics, in order to improve effectiveness of class teaching and build ecological classroom. School teachers should implement ecological concept of sports through consciousness of ecology, mission and culture.

Ecology theory can guide sports class teaching in colleges. We must take a new look at school sports through ecology and establish ecological concept and actively cultivate ecological subject of sports teaching and roundly create good teaching ecological environment, at the same time steadily actuate ecological construction of college sport teaching. The ecologization of sports class teaching still has a long way to go and needs joint efforts. Education departments, colleges, teachers and students as well as the society must make joint efforts to realize ecologization of sports class teaching.

\section{CONCLUSION}

Sports can effectively promote students' integrated development. In the era calling for systematicness, integration, balance and harmony, sports teaching also need balance and sustainable development. Researching sports teaching under ecology can promote harmonious development of sports teaching. However, at present, ecologization of sports class teaching in colleges has problems such as the imbalance of ecological system of sports class teaching, the absence of students' dominant position and the backwardness of sports culture on campus. Colleges must establish ecological teaching thought, cultivate subjects of sports class teaching and roundly create good ecological environment of sports class teaching, in order to strengthen the ecological construction of sports class teaching and realize internal coordinated development and long-term development of sports cause.

\section{REFERENCES}

[1] Zhou Ke. Absence of Ecologization of College Sports Teaching in Contemporary China [J], Management Engineer, 2013(3)

[2] Lan Ruigao, Wang Biao. Reconstruction of Ecologization of College Sports Teaching-from the Perspective of Ecology [J], Pioneering with Science and Technology Monthly, 2012(11)

[3] Feng Zhenwei, Research on "Green" Teaching Idea in College Sports [J], Contemporary Sports Technology, 2013(3) 
[4] Pan Jingmin. Ecological Structure of College Sports Teaching and Development Trend [J], Journal of Shenyang Sport University, 2012(8)

[5] Feng Zhenwei. Analysis on Ecologization of College Sports Teaching under the Perspective of Educational Ecology [J], Sports, 2014(1)

[6] Qiu Youwang. Influence Factor of Sports Teaching Ecologization and Construction of Ecological Sports Course [J], Journal of Nanjing Sport Institute, 2008(12)

[7] Zhang Jing. Absence of Ecologization of College Sports Teaching in New Period and Reconstruction [J], Sports, 2013 (4) 